\title{
LA EVOLUCIÓN ESPIRITUAL DE LA MONARQUÍA HISPANA DURANTE EL PERÍODO DENOMINADO «POSTRIDENTISMO»
}

\author{
JOSÉ MARTÍNEZ MILLÁN ${ }^{1}$
}

RESUMEN: El concepto "postridentismo» se aplica para designar la ideología religiosa después del concilio de Trento (1563) hasta el siglo XVIII. Esta ideología fue asumida por la Monarquía hispana, que la implantó en todos sus reinos y la defendió por las armas contra todos sus enemigos. Se deduce de esta interpretación, primero, que hubo una identificación entre la ideología e intereses defendidos por la iglesia y los defendidos por los monarcas hispanos; segundo, esta armonía religiosa se mantuvo invariable durante los siglos XVI y XVII. Un estudio detenido de la evolución histórica de la Monarquía hispana durante ambos siglos demuestra que, primero, no hubo comunidad de intereses entre la Iglesia y España durante el siglo XVI; segundo, en el hecho de que la ideología religiosa fue distinta en el siglo XVII. Ello se observa, incluso, que durante el siglo XVI la Monarquía hispana se construyó de acuerdo con la idea de "Monarquía Universal» y durante el siglo XVII bajo el concepto de "Monarquía Católica».

Palabras clave: Postridentismo; Monarquía Católica; Monarquía Universal; ideología religiosa.

\section{The evolution of the religious ideology of the Hispanic Monarchy during the period called "post-tridentism»}

ABSTRACT: The concept "post-tridentism» is applied to designate religious ideology after the Council of Trent (1563) until the 18th century. This ideology was assumed by the Hispanic Monarchy, which implanted it in all its kingdoms and defended it by arms against all its enemies. From this interpretation, we can deduct: first, that there was an identification between the ideology and interests defended by the church and those defended by the Hispanic monarchs; second, this religious harmony remained unchanged during the 16th and 17th centuries. A careful study of the historical evolution of the Hispanic Monarchy during both centuries shows, first, that there was no community of interests between the Church and Spain during the 16th century; second, that religious ideology was different in the 17th century. This is even observed in the fact that during the 16th century the

1 Catedrático de Historia Moderna. Universidad Autónoma de Madrid. Correo electrónico: jose.millan@uam.es. 
Hispanic Monarchy was built according to the idea of "Universal Monarchy" and during the 17th century under the concept of "Catholic Monarchy».

KEY WORDS: Post-tridentism; Catholic Monarchy; Universal Monarchy; religious ideology.

\section{INTRODUCCIÓN}

En las numerosas conversaciones que mantuve con el P. Manuel Revuelta, en los últimos veinte años de su vida, siempre procedimos de la misma manera: después de preguntarme por mi familia y por mis hijos (le agradaba especialmente que le contase su evolución física y humana) y de comentar los principales sucesos que nos habían sucedido desde la última vez que nos habíamos visto, terminábamos hablando sobre las investigaciones que teníamos entre manos y las dificultades que nos planteaban los temas estudiados. Confieso que él se sintió intrigado por los trabajos que yo estaba realizando sobre temas de la Monarquía de los Austria y la religión o de la Compañía de Jesús, y no comprendía muy bien que yo le hablase de Monarchia Universalis y Monarquía Católica, en cuya elaboración del concepto, también jugó su papel la Compañía de Jesús. La hora de comer u otra ocupación, que teníamos programada en agenda, interrumpían nuestra conversación cuando más interesante se ponía, de manera que nunca concluíamos el tema; aunque quiero pensar también, que él la provocaba, tal vez, para dar ocasión (sin pedírmelo) a que le hiciese una nueva visita, que él esperaba con alegría.

Considero que la ocasión que se me brinda para recordar su memoria, me permite acabar nuestra cálida conversación por largos años mantenida y, en las pocas páginas que dispongo, quiero presentar un apretado resumen de mi argumentación (ahora sin interrupción) valiéndome para ello de mis investigaciones publicadas, acompañadas de mis últimas lecturas.

La historiografía española (tanto la realizada por laicos como por eclesiásticos) cuando explica la religiosidad de los siglos XVI (segunda mitad) y XVII la califican de "postridentina» (me remito a los Manuales universitarios), esto es, la que se difundió por toda Europa una vez finalizado el concilio de Trento (1545-1563) y, al mismo tiempo, consideran al rey Felipe II (que puso todo su empeño e influencia para que se celebrase la tercera etapa, 1562-1563, de dicho Concilio) el Rey más Católico de la historia de España, pues además, dos años después (1565), ordenó aplicar los acuerdos de Trento en todos sus reinos, mediante la celebración de Concilios provinciales tanto en sus reinos peninsulares como en los virreinatos Americanos. 
Sin embargo, cuando se contempla el reinado de Felipe II y se analizan las relaciones que mantuvo con la Santa Sede, se observa que el Rey Prudente mantuvo un continuo enfrentamiento con el papado a causa de las intromisiones que el monarca asumía en cuestiones eclesiásticas y por las invasiones jurisdiccionales que las justicias reales hacían en el campo eclesiástico. Recuérdese que el Rey Prudente estableció los acuerdos de Trento en sus reinos en conexión con sus intereses políticos (para lo que envió a sus ministros y teólogos a los Concilios provinciales, desoyendo las advertencias de Roma) y, sobre todo, impuso los célebres «recursos de fuerza», aplicados cuando surgía un enfrentamiento entre ambas jurisdicciones, mientras que el Pontífice solo se podía oponer con la bula In Coena Domini. No resulta extraño ni es una leyenda la expresión que Pío V le escribió a su nuncio en Madrid para que la trasmitiese a Felipe II: «... y decidle que es el monarca menos cristiano que ha existido en la historia».

Por otra parte, las relaciones de la Monarquía hispana con la Santa Sede durante el siglo XVII no fueron tan problemáticas. Desde luego, fueron pacíficas durante el reinado de Felipe III (1598-1621) y también durante el reinado de Felipe IV (1621-1665), si bien, en algún momento hubo duras acusaciones y enfrentamientos, que llegaron, incluso, a ruptura diplomática durante los años centrales (década 1630) de la guerra de los Treinta Años, en tiempos del papa Urbano VIII, como bien estudió el P. Quintín Aldea.

En resumen, un sencillo recorrido a través de los tiempos posteriores al concilio de Trento (sin hacer referencia a doctrina ni ideología religiosa) demuestra que hay un contraste en las relaciones con la Santa Sede entre el reinado de Felipe II (1555-1598) y el de sus sucesores (siglo XVII), lo que induce a pensar que el término "postridentismo» no resulta unívoco ni tuvo el mismo significado en el siglo XVI que en el XVII. A pesar de todo, los historiadores lo siguen utilizando uniformemente con lo que se incurren en agudas contradicciones.

\section{LA FORMACIÓN DE LA MONARQUÍA HISPANA COMO MONARCHIA UNIVERSALIS}

El conglomerado de reinos y territorios cuya entidad fue percibida en Europa durante el siglo XVI como "Monarquía hispana» se configuró en torno a la vieja idea de Monarchia Universalis. A través de este proyecto, la Corona de Castilla mantuvo unidos a todos los reinos que sus monarcas fueron adquiriendo por herencia o conquista. Ahora bien, la Monarchia Universalis, que 
asumieron los monarcas hispanos y que sirvió de justificación a su actuación política, por sus peculiares orígenes, fue algo muy diferente del concepto tradicional. Las monarquías anteriores, que se habían proclamado «universales», sirvieron siempre de modelos, pero no admitieron una legitimación histórica como la hispana, basada en la tradición medieval (La Reconquista: guerra contra el infiel durante ocho siglos) y en los privilegios concedidos por los pontífices para llevar a cabo su expansión a ultramar (bulas de Alejandro VI). La Monarquía española no se presentó como un Imperio a pesar de que su monarca, Carlos V, llegó a ocupar simultáneamente la dignidad imperial, sino como un «Reino universal» capaz de realizarse materialmente (Mattei, 1965 y 1952). En este sentido, el poder del rey de España fue distinto del modelo imperial, aunque tenía una forma similar, pero también fue diferente de la «Monarquía Universal» tradicional. Las condiciones por las que la Monarquía hispana se apoderó de la idea de la «monarquía universal»se apoyó en dos factores esenciales: la pérdida de liderazgo del Imperio como fuerza política en Europa (tenía menos poder que la Monarquía hispana) y la aspiración de Castilla a desarrollar competencias para-imperiales en virtud de su propia historia (cruzada medieval) y de los privilegios concedidos por los pontífices para expandir el cristianismo (bulas alejandrinas), que le permitieron subordinar la religión en su propio provecho político.

En mi opinión, la idea de Monarchia Universalis, que asumió la Monarquía hispana, se forjó durante la regencia de Fernando el Católico (15071516) y los primeros años del reinado de su nieto, Carlos V (1517-1556), y fue el resultado de la confluencia de distintas corrientes ideológicas que, aparentemente pretendían un mismo objetivo, pero sus orígenes y justificaciones fueron muy diversos. De cualquier manera, todas estas corrientes que fundamentaron la estructura de poder tan peculiar (que en esencia consistió en la subordinación del poder del pontífice a los intereses políticos del rey hispano), estuvieron relacionadas con la religión cristiana y con la organización política medieval (la Cristiandad).

Aunque la gestación de esta idea comenzó con la expansión de Fernando el Católico a la península italiana, tras la conquista de Nápoles y la solicitud de protección del papado al Rey aragonés ante los numerosos enemigos que le acosaban, la idea política cuajó tras el saqueo de Roma (6 de mayo 1527). Durante varios meses Roma estuvo devastada por el ejército del Emperador y solo se interrumpió el saqueo a finales de agosto por el temor de haber surgido la peste. En todo este tiempo, la Cristiandad estuvo sin guía. El papa, vicario de Cristo en la tierra, enmudeció. La corte de Carlos V tardó en responder a todos los interrogantes planteados por la Cristiandad, que se encontraba sin cabeza. Ante esta inédita situación, el Emperador necesitaba 
una solución que nadie sabía formular: era el momento de desplazar a los consejeros flamencos (que desde su adolescencia venían asesorándole en política) y de acudir a los «españoles» (es decir, a los políticos que habían asumido las ideas de Fernando el Católico como Francisco de los Cobos o Juan Tavera) y de Gattinara (el único consejero de Carlos V que había llegado a Castilla desde Flandes, que no era flamenco ni compartía las ideas de ellos).

Ante tan delicada situación, había que preparar con mucha cautela lo que se debía hacer y Gattinara presentó una solución de consenso, mientras que el humanista Alfonso de Valdés ponía en palabras del dios Mercurio el papel que le correspondía al Emperador en esta nueva situación, la de imponer el orden por encima del papa; esto es, asumir la idea política de la Monarchia Universalis. En sus escritos estaba dando, más que la opinión de su amigo Erasmo, las ideas humanistas con sesgo gibelista defendidas por Gattinara; no en vano, Valdés desarrollaba sus funciones administrativas en las oficinas del Gran Canciller.

Para Gattinara, lo inmediato era tranquilizar a los príncipes de la Cristiandad despejando todo temor y justificar la acción del saqueo (Rivero Rodríguez, 2005, pp. 83-96). Para ello, Gattinara bosquejó una idea ingeniosa: adoptaba como propia la visión italiana, tradicionalmente esgrimida por la Santa Sede como justificación de su poder temporal, al ofrecer una imagen pacífica, donde el Emperador, con su viaje a Italia, se presentaría no como invasor o dominador sino como protector, actitud que después fue saludada por quienes, poco antes, habían defendido el poder temporal de la Iglesia como único fiel de la balanza italiana y única garantía de paz (Guicciardini, 1890, p. 290). Asimismo, el Gran Canciller recuperó e hizo propia la tradición hispana (el pensamiento de Fernando el Católico): Milán era prioritario para dominar Italia. Esto puede parecer sorprendente, pero entre los cortesanos españoles se concedió una importancia secundaria al Sacco, dando mayor prioridad a los debates en torno a la muerte del condestable de Borbón y las consecuencias que acarreaba en el dominio de Milán. Por último, se trató de enlazar el Sacco con un ambiente de esperanza y confianza en la apertura de un proceso de regeneración de la Iglesia (Rodríguez Villa, 2011, pp. 186 y 254). Gattinara así lo quiso dar a entender por medio del secretario Alfonso de Valdés, al que autorizó a difundir el vibrante Diálogo entre Lactancio y un arcediano, en defensa del Emperador, marcando un tiempo de renovación y esperanza (Vian Herrero, 1994, pp. 42-47). Utilizando la Querella pacis de Erasmo, Alfonso de Valdés, escribió una obra en la que planteaba los derechos y deberes del papa en materia política porque el debate era precisamente entre el Emperador y el Pontífice. En el fondo lo que se trataba era de la significación del papado. Misión del papa era continuar la obra de 
Cristo y encarnar el espíritu evangélico, sin embargo, se dedicaba a ampliar sus dominios temporales, por lo que correspondía al Emperador, de acuerdo con la interpretación de la Monarchia Universalis, asumir y realizar la tarea de reforma. De esta manera, el Emperador aparecía como el defensor de la fe, al que correspondía la liquidación del asunto de Lutero y la reforma de la Cristiandad, dada la pasividad del pontífice. La paz a la que aspiraba el Emperador era una paz universal y tenía en la realidad de los hechos un sentido defensivo basado en la hegemonía que gozaba de hecho.

No obstante, si la práctica política de Carlos como «monarca universal» estuvo yuxtapuesta por su título de Emperador, a partir de 1555, cuando Carlos dividió sus territorios entre su hijo, a quien dejó los reinos patrimoniales (Monarquía) y a su hermano Fernando, la dignidad imperial, la Monarquía hispana apareció ejerciendo su actividad política claramente como Monarchía Universalis. A partir de 1561, Felipe II ejerció, desde Madrid, el liderazgo sobre el linaje y trató de orientar la política común de ambas ramas (la de España y la del Imperio) de acuerdo a unos ideales católicos, pero subordinados a los intereses políticos de su Monarquía. La preeminencia política de la rama española sobre el Imperio y el resto de monarquías europeas se justificaba desde el punto de vista práctico: la Monarquía hispana era la más poderosa. Por consiguiente, el concepto de «Monarquía Universal» fue rellenado con las ideas políticas y religiosas castellanas.

Durante el reinado de Felipe II, un grupo de poder — al que se le ha bautizado con el epíteto de «castellano»— consiguió situarse en los cargos principales del gobierno de la Monarquía e imponer una política y una ideología religiosa de acuerdo con sus creencias (forjadas en la Edad Media). Dicho grupo estaba integrado mayormente por letrados, que mayoritariamente habían estudiado en la Universidad de Salamanca, pertenecientes a las elites castellanas, quienes relegaron del poder a los representantes sociales tanto de Castilla como de los otros reinos que componían la Monarquía, rompiendo la concordia y el sistema de integración que Carlos V había utilizado con éxito. Roma no era ajena a este malestar, toda vez que los pontífices, como señores temporales, venían padeciendo el mismo sometimiento y amenaza por parte del monarca hispano. Las mayores desazones que padecía el papado consistían, por una parte, en la influencia decisiva que venían ejerciendo la Monarquía hispana en los cónclaves a la hora de elegir a los pontífices a través de la red clientelar de cardenales que habían construido valiéndose de su poderío temporal (Hinojosa,1896, pp. 399-405); por otra, en la injerencia que Felipe II hacía en temas de jurisdicción eclesiástica y de reforma religiosa a través de los «recursos de fuerza». 


\section{LA QUIEBRA DE LA MONARCHIA UNIVERSALIS}

El rígido control ideológico que Felipe II había establecido sobre la sociedad (reformó la Inquisición) y la formalista interpretación de la doctrina católica, vinculada a la política, impuesta en sus reinos, hizo surgir profundas discrepancias, no solo en el ámbito social y político, sino también dentro de la religiosidad y vivencia espiritual: apareciendo grupos de frailes dentro de las Órdenes religiosas que aspiraban a un radicalismo religioso y una espiritualidad más personal, conocidos como el movimiento de la descalcez. Esta corriente, típicamente española, sintonizaban con los ideales de las corrientes radicales surgidas a principios del siglo XVI en Italia (tales como la de San Felipe de Neri), lo que contradecía el espíritu reformista "controlado» por el Rey Prudente. De este modo, se producía una situación en la que los intereses políticos y las tendencias religiosas se superponían, de manera que las reivindicaciones políticas de los reinos en el modo de gobernar (contrarios a los ideales "castellanos») respaldaban las tendencias espirituales defendidas por Roma (era el pontífice quien debía definir la ortodoxia religiosa) y rechazaban la impuesta por el Rey Católico y sus asesores.

Pero, además, para conseguir que la Iglesia consiguiera su autonomía como una institución religiosa, al margen de los poderes políticos que defendían su confesión, no solo bastaba con desprenderse del dominio español en Italia y su influencia en la curia, sino también era preciso controlar la expansión del cristianismo por el mundo a través de las nuevas órdenes religiosas que habían surgido: jesuitas y «descalzos». Para dirigir esta expansión (sin contar con la ayuda política y militar de la Monarquía hispana o de otros poderes políticos) era necesario crear una institución que centralizase y proyectase todas las actividades en esta materia: la Sagrada Congregación de la Propaganda Fide. La fundación de la Congregación de la Propaganda Fide surgió tras un largo período de gestación que arranca de los últimos años del reinado de Felipe II (Santos, 1972). La importancia de la Congregación resulta fácil de deducir si se tiene en cuenta que la expansión del cristianismo ya no fue llevada a cabo por la Monarquía hispana, sino por la propia Iglesia. Bajo el pontificado de Paulo V (1605-1621), la evangelización cobró un nuevo impulso, gracias al esfuerzo que el papa puso en la diplomacia como condicionante para desarrollar las misiones. Finalmente, fue el papa Gregorio XV, quien fundó la Congregación de la Propaganda Fide el 6 de enero 1622. El modo que adoptó la «Congregación» de difundir el catolicismo por el mundo fue pacífico (basándose en la predicación y ejemplo personal de los misioneros), mientras que la Monarquía universal de Felipe II era a través de las armas. 
Ahora bien, el triunfo la espiritualidad radical en la corte hispana no se debió solamente al esfuerzo y predicación realizados por los sectores descalzos, sino que fue un proyecto complejo, apoyado desde Roma. El objetivo primordial de la Santa Sede para romper el sistema político hispano, justificado en la religión, era destruir el control que el Rey Católico había establecido en la curia. Aunque los pontífices de la segunda mitad del siglo XVI venían intentando independizarse de está coadyuvante influencia, la situación no estuvo preparada hasta el pontificado de Clemente VIII (15921605) (Fattori, 2004).

A partir de este pontificado, la Iglesia consiguió establecer una nueva impronta sobre la producción religiosa y sobre el modelo cultural católico. Para ello, la Santa Sede desplegó una doble estrategia: por un lado, impedir la disensión religiosa en la forma de saber alternativo; para evitarlo, utilizó la Inquisición y el Índice de libros prohibidos; por otro, Clemente VIII promovió el conocimiento de los contenidos de la fe para reducir al mínimo las desviaciones ideológicas, utilizando para ello a los intelectuales eclesiásticos ortodoxos. De esta manera, emergió un sistema unitario de estudios, contrapuesto al período precedente (el humanista), que consistió en articular el saber humanístico con el «nuevo» saber teológico, y que fue difundido gracias a la actividad de las nuevas órdenes religiosas, especialmente, jesuitas y oratorianos (Dupront, 1975, pp. 296-307). Entre 1580 y 1590 se multiplicaron las grandes obras sistemáticas que contenían una renovada energía de la institución eclesiástica, pero mientras los humanistas habían promovido un saber independiente del teológico, el espíritu contrarreformista que desplegó la Iglesia, en la coyuntura entre los siglos XVI-XVII, favoreció el desquite teológico que redujo los studia humanitatis a una mera función gramatical y retórica, situándolos en una especie de filosofía auxiliar que servía como reserva de argumentos en defensa de la posición de la fe dentro de unos límites rigurosamente fijados (Garin, 1957, pp. 194, 212-218).

A partir de entonces, Roma asumió el papel de guía específico y único del mundo católico sin admitir interferencias particularistas en los reinos, lo que se tradujo en una abundante creación intelectual. Excelentes estudios han analizado el ambiente jesuita romano y la función que desempeñó el Colegio Romano como lugar de formación intelectual y cristiana en la primera fase de este proceso (Ginnes, 1995), al igual que el significado de la instrucción jesuítica y la peculiaridad de la Ratio studiorum, que, desde 1599, permaneció inmutable por dos siglos como ley de los colegios de la Orden y de modelo de formación de los jóvenes (Brizzi, 1981; Labrador, Bertrán-Quera, Diez Escanciano, Martínez de la Escalera, 1986; Baffetti, 1997; Duminuco, 2000). 
Asimismo, la aplicación de esta religiosidad a la vida práctica social se llevó a través del Oratorio de san Felipe Neri (Frajese, 1995; Cistellini, 1989, I, pp. 55 ss; Impagliazzo, 1995), que se distinguió de la Compañía de Jesús por la ausencia de una disciplina doctrinal y defendió una espiritualidad pacífica, que se debía ver reflejada en el ejemplo personal de sus seguidores. La moral, que venía unida a la teología del dogma como justificación de su propia existencia, se separó de la dogmática y comenzó a enseñarse como disciplina autónoma; de esta manera aparecieron los tratados de teología moral como nuevo género literario y a moldear un nuevo paradigma de cristiano. En torno a la confesión se produjo todo un auténtico programa para el penitente y para el sacerdote, ministro de la penitencia, que tenía que saber juzgar sobre la gravedad de los pecados.

En resumen, el modelo religioso surgido desde Roma consistió en implantar un ascetismo como práctica de las virtudes, que permitía a los hombres llegar a la perfección cristiana y alcanzar su salvación; pero, la virtud también implicaba una disposición del alma, que se trasmitía al exterior a través de las acciones concordes con los mandatos de la Iglesia. En este sistema, el ejercicio de la virtud se convirtió en la columna de la convivencia humana. Ahora bien, el ánimo virtuoso debía mostrar señales para que lo identificasen en el ámbito social. Los miembros de la Compañía de Jesús y de las órdenes descalzas contribuyeron activamente a difundir aquel modelo de perfecto católico, inserto dentro de la ética cristiana y fundamentado en la teología católica, que subordinaba toda la vida del cristiano a los principios dispuestos desde Roma.

\section{LA CREACIÓN DEL CONCEPTO POLÍTICO DE «MONARQUÍA CATÓLICA»}

La transformación que experimentó la Monarquía hispana (como Monarchia Universalis) hasta convertirse en Monarquía Católica se realizó durante los reinados de Felipe III (1598-1621) y Felipe IV (1621-1665) y se manifestó en los numerosos escritos que defendían la subordinación de la Monarquía al poder de la Iglesia. El agotamiento económico y militar, que estaba padeciendo la Monarquía hispana con motivo de la guerra de los Treinta Años, favorecía la aplicación de esta teoría ante la impotencia que padecía para mantener su hegemonía. Roma aprovechó esta circunstancia para impulsar la unión de la Monarquía hispana con el Imperio, siempre obediente a Roma, poniendo como columna de la grandeza la dinastía (Habsburgo). Para ello 
resucitó el mito del duque Rodolfo, fundador de la dinastía, quien había prestado su caballo, en medio del bosque, a un sacerdote que llevaba el viatico a un pobre moribundo. El religioso le profetizó que su descendencia lograría formar un gran imperio por el gesto humilde que había mostrado hacia la Eucaristía. A partir de entonces, se impuso un nuevo discurso legitimador de la Monarquía centrado en la casa de Austria y desechando la ideología castellana de los "godos» y las aventuras militares de la Monarquía hispana como difusora del cristianismo. Para sellar esta alianza de igualdad entre las dos ramas de la dinastía, se le aplicó un fin trascendente, reflejado en la devoción a la Eucaristía, símbolo de la Iglesia. La grandeza de la dinastía se había generado por la defensa que todos sus monarcas habían realizado de la Iglesia. Era necesario, por tanto, que la Monarquía hispana abandonase sus veleidades de poder universal (Monarchia Universalis), insertas en la cultura castellana, y emplease sus fuerzas en la defensa de la Iglesia de Roma en unión con el Imperio («Monarquía Católica»).

Desde el punto de vista del pensamiento político, el concepto de «Monarquía católica» se oponía a las ideas y prácticas políticas defendidas por Maquiavelo, pero también a la subordinación de la autoridad del papa a la del «monarca universal». El primer teórico que explicó la relación de fuerzas que debía existir en esta nueva situación fue fray Juan de la Puente, quien, en 1612, publicaba un libro, dirigido «al gloriosísimo Filipo Ermenegildo, nuestro señor Emperador de las Españas, y señor de la mayor Monarquía que an tenido los hombres desde la creación hasta el siglo presente». En la dedicatoria dirigida «Al Reyno junto en Cortes», que titulaba «Declaración del blasón que está en la cabeça deste libro» (Puente, 1612, 1v-2r), explicaba el contenido de todo el tratado:

Moysen en la historia que hizo de la creación del mundo dice: Que el día quarto hizo Dios dos grandes luminarias. Esta sentencia se halla en la cabeça del blasón. Estas dos grandes luminarias son el Sol y la Luna, cuyas imágenes ponemos sobre las dos columnas. [...] el Sol es símbolo de la potestad espiritual, que reside en el Papa, y la Luna símbolo de la potencia temporal del mayor de los Reyes [...] Siguiendo esta alegoría, pongo junto al Sol las armas del Pontífice Romano, cabeça de la Iglesia universal y junto a la Luna el escudo del Rey Nuestro Señor, Monarca del Imperio Español. Entre la imagen del Sol y las armas de la Iglesia, va esta sentencia compuesta de las palabras de Moysen y de otras que se añaden para declarar la significación del emblema: La lumbrera mayor para que presida en la ciudad y en el mundo. No será necesario prouar que la palabra latina Urbs significa Roma [...] Entre las armas del Rey nuestro señor y la imagen de la Luna, media esta sentencia: la lumbrera menor para que obedezca a la ciudad y sea señora del mundo [...] Los dos escudos enlazados, y inclinados el uno hazia el otro, significan el amor y unidad que siempre an conseruado entre sí las dos Monarquías Católicas. La figura de muger en hábito graue y triunfante, que está 
a la mano derecha, es la imagen de Roma, cabeça de la Monarquía Eclesiástica; la que está a su lado, es España, cabeça de la Monarquía Católica.

Desde semejantes planteamientos resultaba muy fácil señalar la justificación existencial de la Monarquía y la conducta que debían seguir sus monarcas. Numerosos escritores (pertenecientes a las órdenes descalzas) desarrollaron la idea: fray Juan de Santamaría, franciscano descalzo, escribió su Tratado de República y policia christiana. Para Reynos y príncipes, y para los que en el gobierno tienen sus veces (1615), en el que señalaba que lo más importante en el gobierno de un príncipe católico era que «los reyes mantengan la Fe, y religión, la conserven, y aumenten en todos sus Reynos, y provincias; $y$ que para esto es muy necessaria la obediencia, y respeto a los Sumos Pontífices Romanos». Asimismo, insistía en recordar la devoción que la Casa de Austria siempre había tenido a la Santa Sede, por lo que aconsejaba al monarca hispano que debía estar: "por todo subjeto, y obediente a la Santa Sede Apostolica Romana, y al Vicario de Christo, que en su lugar la govierna, sin superior en la tierra a quien los Reyes, y todas las gentes della deven respeto, humillación, y reverencia» ${ }^{2}$.

En el intento de mostrar el origen común de las dos ramas de la dinastía y olvidar la tradición política castellana, los tratadistas de la época reconstruyeron la leyenda de Rodolfo aplicándola a la devoción que los Habsburgo españoles habían manifestado siempre al sacramento de la Eucaristía. Dichos cronistas reinventaron la hazaña del encuentro del monarca con el viático aplicándola a Carlos V, primer Habsburgo hispano. Según la leyenda, en cierta jornada que Carlos V caminaba por la Plaza Mayor de Valladolid tropezó con un sacerdote que portaba el viático y, apeándose del caballo, se hincó de rodillas humildemente en el lodo del suelo adorando la Eucaristía. Felipe II imitó posteriormente el gesto de su padre, según narraba el benedictino Fray Juan de Salazar en su obra Política Española de 1619, obra que dedicó al príncipe, futuro Felipe IV, cuando Salazar era procurador de su Orden, residente en Roma (Salazar, 1619). El cronista José Pellicer y Tovar, en su libro La fama Austriaca (1641), defendía las proezas y la piedad del emperador Fernando II, quien siempre había luchado en defensa de la Iglesia Católica. Es más, en otra de sus obras, trataba de entroncar la genealogía del príncipe Baltasar Carlos (a quien dedicaba la obra) con Adán, insinuando la vinculación la casa de Austria con la divinidad.

2 Tratado de República y policía christiana para Reynos y príncipes y para los que con el gobierno tienen sus veces. Compuesto por Fray Juan de Santa Maria, religioso descalço, de la provincia de San Joseph, de la Orden de nuestro glorioso Padre San Francisco (1617) Barcelona, 243r-244r (BNE 2/41638). 
Con todo, para que esta nueva justificación ideológica de la Monarquía fuera asumida por la sociedad hubo que incorporar una serie de elementos externos, acordes con la confesión católica, formulada por Roma, fáciles de asimilar. Para ello, nada mejor que implantarlos en el Palacio Real con el objeto de que fuesen asimilados por los cortesanos:

El primer elemento que manifestó el influjo de Roma en la Monarquía Católica fue en el traslado que se hizo de las ceremonias y etiquetas de la capilla papal a la capilla real del Alcázar de Madrid, sede del monarca hispano. De acuerdo con la nueva misión política que se le encomendaba a la Monarquía (la defensa de la Eucaristía), el segundo elemento religioso que se impuso fue el establecimiento del Santísimo Sacramento de manera perpetua en la capilla del Alcázar, que sorprendentemente aún no existía. Con esta práctica religiosa se erradicaba definitivamente la aspiración «de universalidad» que traslucía la actividad de la Monarquía hispana (hasta el punto de considerarse superior al Imperio), justificada en una construcción ideológica de valores autóctonos (castellanos), para situarla en plano de igualdad política con el Imperio, uniéndolos en un origen común (la dinastía Habsburgo) y en una misma misión (la defensa de la Iglesia católica), expresada religiosamente en la devoción al sacramento de la Eucaristía. En este contexto, el 10 de marzo de 1639, se accedía a la petición del Patriarca de colocar el Santísimo Sacramento en la capilla real. El P. Aguado sacaba a la luz su obra Sumo Sacramento de la Fe, Thesoro Christiano, en 1640, dedicada a Felipe IV, en la que declaraba que el sacramento más importante era la Eucaristía. Por aquellos tiempos, el P. Nieremberg se había convertido en uno de los jesuitas más influyentes de la corte hispana, cuyos escritos incorporaron la nueva ideología religiosa que Roma pretendía implantar ${ }^{3}$. Con todo, el elemento principal fue la culminación del triunfo de Roma y de su espiritualidad radical sobre la Monarquía fue la implantación de la devoción de las Cuarenta Horas en la capilla real del Alcázar. Esta práctica religiosa, que había surgido durante la primera mitad del siglo XVI en Italia, fue asumida por Felipe IV ${ }^{4}$. El propio monarca no dudaba en recurrir a la práctica de las «Cuarenta Horas», al considerar que el sacramento de la Eucaristía era el que devolvería a la dinastía su gloria ${ }^{5}$. Se acababa así con la imagen de una Monarquía «belicista». El

3 Nieremberg, J. E. (1642). Causa y remedio de los males públicos. Dedicado al Excelentissimo Señor don Gaspar de Guzmán Conde Duque, 36. (BNE, 3/67902).

4 Bulla de la Santidad de Inocencio X en que concede a la Real Capilla de S. M. perpetuamente para el culto y veneración del Santísimo Sacramento en dicha Real Capilla (1646). (AGP. Real Capilla, caja 2, exp. 5, fol. 2).

5 De Madrid y Febrero 21 de 1640, Sebastián González al P. Rafael Pereyra, de la Compañía de Jesús, en Sevilla. En, Gayangos y Arce, P. (1862), "Cartas de algunos 
capellán Vicente Tortoretti afirmaba en su obra sobre el Santísimo Sacramento que: "Más pelea V. Magestad con la punta de su pluma, y en un día, que otros en años con el estoque. Y porque tiene muchos enemigos, y mucho que acudir, es fuerça que esta arma [el Cuerpo de Cristo] tenga buen temple para herir, y para resistir; todo lo puede, aunque sea pluma de un cisne». ${ }^{6}$ A partir de entonces, las frecuentes celebraciones de palacio en honor a la Sagrada Forma implicaban la presencia de las principales órdenes religiosas. Así, en marzo de 1639, el jesuita P. Sebastián González informaba desde Madrid al P. Rafael Pereyra sobre la implicación de los clérigos regulares en las fiestas del Corpus.

\section{EL NUEVO IDEAL RELIGIOSO DE ROMA Y LA SUMISIÓN DE LA MONARQUÍA CATÓLICA}

La Congregación Propaganda Fide fue extendiendo decretos y promulgando instrucciones, durante los primeros años de existencia, que se enviaban a los capítulos generales celebrados por las distintas órdenes religiosas con el fin de que actuaran de acuerdo a ellos. No obstante, en 1659, la Congregación extendió una larga Instrucción que resumía todos los decretos promulgados hasta entonces, por lo que dicho documento se puede considerar como el punto de partida programático de la Congregación y del espíritu que hasta entonces había reinado en ella. De hecho, durante mucho tiempo, esta Instrucción vino a ser como el «manual» para las misiones de la Propaganda. Lo sorprendente es que los primeros objetivos de la expansión católica fueron Europa y América, territorios que ya eran católicos, por lo que se supone que no solo era la expansión del catolicismo, sino un catolicismo concreto, de acuerdo a los ideales y la espiritualidad proyectados por Roma y no por el monarca universal. ¿Cuál era, entonces, el contenido ideológico y la espiritualidad que los misioneros de la Congregación Propaganda Fide querían imponer por el mundo?

PP. de la Compañía de Jesús sobre los sucesos de la Monarquía entre los años de 1634 y 1648. Tomo III (1638-1640)», en: Memorial Histórico Español: colección de documentos, opúsculos y antigüedades, que publica La Real Academia de la Historia. Madrid, Imprenta Nacional, XV, p. 414.

6 Maximiliano Socorrido y fragmento Eucharisticos recogidos en la colocación del Sanctissimo en la capilla real del rei nuestro Señor don Filipe IV. El Grande. Por D. Vicente Tortoretti su humilde Capellán. 1639, f. 18v. (BNE, 3/33006). 
Ante la indisponibilidad de tener misioneros propios, formados o controlados por la Congregación, ésta tuvo que acudir en sus comienzos a las órdenes misioneras que ya trabajaban desde hacía tiempo en la conversión de los infieles. Además, buscó en el clero regular nuevas fuerzas que vinieran a colaborar el apostolado misional. Fue así como las distintas órdenes religiosas vinieron a colaborar con la Congregación de Propaganda Fide: los jesuitas y carmelitas descalzos fueron los primeros. Vitelleschi se puso en manos de la Congregación a la Compañía de Jesús. El general de los capuchinos, Clemente de Noro, en carta de 12 julio 1622, también se ponía a disposición de la nueva Congregación. La Propaganda comenzó a seleccionar misioneros, obedientes a las instrucciones de la Congregación, prontos en comunicar a Roma noticias y su apostolado, ajenos a la autoridad secular del Patronato (Kowalsky, 1965).

La idea de crear el Colegio Urbano en Roma provino del mismo espíritu misionero de Propaganda. El 1 de junio de 1626, con la aprobación del Pontífice, Juan Bautista Vives concedía una renta anual de 715 escudos con los que fundaba la ayuda económica para 12 alumnos, bajados a 10 porque las rentas no bastaban (Pizarro Llorente, 2017). Por su parte, el Oratorio de Felipe Neri, a diferencia de otras instituciones coetáneas, aún apenas había hecho su aparición (exceptuando algunos de sus hombres) en la escena política. En sus primeras décadas, la familia oratoriana fue un oasis de intensa vida espiritual, puesta al servicio del corazón de la Ciudad al servicio de la Iglesia y en función de instrumento de reforma eficaz, toda recogida en su peculiar estructura. "Quien hace bien a Roma, hace bien a todo el mundo», es un consejo del padre Felipe, frecuentemente repetido también por los suyos.

La fundación religiosa de Felipe Neri nunca fue bien vista en la Monarquía Católica. La obra de Neri, nacida en medio del ambiente reformador del siglo XVI, con el objetivo de restaurar la grandeza espiritual de Roma, como cabeza de la cristiandad, tras la humillación que padeció a manos de las tropas imperiales en 1527, iba en contra de los ideales políticos-religiosos de la Monarchia Universalis hispana cuyo monarca utilizaba la religión para justificar sus proyectos políticos. Todo ello produjo un callado resquemor y una constante desconfianza por parte del gobierno hispano hacia esta institución religiosa. Resulta lógico, por tanto, que el «Oratorio» no se estableciese en la península hasta mitad del siglo XVII y que fuera de manera dificultosa; de hecho, las primeras fundaciones no fueron en la corte, sino en el reino de Valencia. La espiritualidad filipense se instaló en la península gracias a personajes como el Caballero de Gracia quien, «introdujo en Madrid muchos de los ejercicios espirituales del Oratorio de Roma y a su imitación se han fundado después muchas congregaciones en las misma insigne villa y corte 
de nuestros reyes de España» (Alba, 1992, p. 105). Los ejercicios del Oratorio comenzaron a practicarse en la iglesia de san Juan del Hospital de Valencia en 1643, mientras que la primera congregación se fundaba dos años después en una casa cercana. El gran impulsor fue el canónigo valenciano Luis Crespí y Borja, quien con motivo de un viaje a Roma conoció a los sacerdotes de la Congregación romana, prendándose de su forma de vida. Cuando volvió a su tierra, quiso establecer esta organización. Lo que consiguió uniéndose a otros sacerdotes: Felipe Pesantes, Luis Escriba, Jerónimo Pertusa y Diego de Liñán (Bacci, 1673). Crespí fue nombrado obispo de Orihuela en 1651 y seis años más tarde de Plasencia. Desempeñó un importante papel como embajador extraordinario de Felipe IV ante la Santa Sede para conseguir la declaración del dogma de la Inmaculada Concepción, tema que le resultaba cercano porque había publicado su Propugnaculum theologicum (Crespi de Borja, 1653).

En la corte, el espíritu del Oratorio de Neri se difundió a través de una nueva institución, creada en Madrid en torno a 1646, que practicó una espiritualidad similar; nos referimos a la Santa Escuela de Cristo (Valero Moreno, 1986; Martínez Gomis, 2002; Labarga García, 2013). Los orígenes de la Escuela de Cristo estuvieron en el hospital de los Italianos de Madrid (León Pinelo, 1975, p. 165) ${ }^{7}$, donde comenzaron a tener reuniones - a iniciativa de un padre filipense, Juan Bautista Ferruzzo ${ }^{8}$ - a partir de 1646, aunque de forma oficial no comenzaron hasta seis años después (1653). La escuela de Cristo trajo a España el espíritu de san Felipe de Neri, si bien, Juan de Palafox le confirió una peculiar impronta ascética. La congregación filipense de Madrid fue erigida formalmente el 26 de febrero de 1653 por Juan Bautista Ferruzzo.

El fin de la Escuela de Cristo era «el aprovechamiento espiritual de sus miembros y aspirar, en todo, al cumplimiento de la voluntad de Dios, de sus preceptos y consejos, caminando a la perfección, cada uno según su estado y las obligaciones de él». Como afirma el profesor Sánchez Castañer, la Escuela de Cristo no es una fundación para seglares con el objetivo de fomentar el culto o la caridad entre sus miembros o fuera del instituto, sino que su fin es escalar en la perfección ${ }^{9}$. Por ello, lo fundamental no son los

7 La fundación tuvo lugar en tiempos del nuncio Camilo Gaetano (1592-1600), quien puso la primera piedra en 1598. Estaba situado en la Carrera de San Jerónimo esquina con calle Cedaceros de Madrid.

8 Ferruzzo había nacido en Mesina en torno a 1602. Labarga, F. (2011). Ferruzzo, Giovanni Battista, Diccionario Biográfico Español Madrid (XX), 36-38.

9 Sánchez Castañer, F. (1972). Escuelas de Cristo. Diccionario de historia eclesiástica de España. Madrid. CSIC. Volumen I de Suplemento. 
ejercicios semanales que se practican en la Escuela, sino la norma de vida fuera de la institución, como se ordena en su capítulo XIV. Es decir, se trata de una regla de perfección humana. «La Santa Escuela estaba integrada por varones, tanto eclesiásticos como seculares, hasta un máximo de setenta y dos, recordando el número de los discípulos que acompañaban a Cristo» (Labarga García, p. 24).

La organización de la Santa Escuela de Cristo no era nueva, aunque aportaba novedades para la época, pero venía en la línea de lo ya habían practicado las Compañías del Divino Amor, apoyadas por teatinos y barnabitas y, poco después, por el Oratorio de san Felipe Neri. No se sabe con claridad las causas que llevaron a Ferruzzo a fundar en Madrid las Escuelas de Cristo, sino la de difundir la espiritualidad filipense. No obstante, organizaciones semejantes ya existían en Italia y el padre Ferruzzo debía de conocerlas. Algunos historiadores afirman que ya existió esta escuela en Alcalá de Henares, en el colegio de San José, que regentaban los hijos de san Francisco Caracciolo, y que una vez muerto el fundador, Benito Capelo, en 1627, pasaría después a Madrid. Lo que sí es cierto que existían por la época diversas reuniones o instituciones parecidas como las de Valencia o Valladolid, que eran similares a las del Oratorio de san Felipe que, en España no se llegó a implantar hasta 1643 gracias al esfuerzo del padre Luis de Crespí.

Según el gran especialista, Fermín Labarga, llegaron a funcionar más de cuatrocientas Escuelas durante la segunda mitad del siglo XVIII, extendidas por España y América y a ellas pertenecieron personajes tan opuestos como Antonio María Claret, Juan de Palafox, fray Diego de Cádiz, Miguel de Molinos, Nicolás Antonio, Manuel María de Arjona, José María Blanco White o Alberto Lista (García Fuertes, 1992). El carácter discrecional de la Escuela que, en el capítulo XIV de sus constituciones dice «excusen referir a los que no son de la Escuela los ejercicios y cosas particulares de ella», ha contribuido a que tan gran institución no se conozca (Valero Moreno, 1986; Martínez Gomis, 2002).

La Escuela y la red de solidaridad que tejieron sus miembros, constituyó un círculo de poder en el gobierno de los últimos años de Felipe IV y durante la regencia de Mariana de Austria. Buena muestra de ello es que dentro de la Junta de Regencia que dejó el monarca, a su muerte, para que asesorase a su esposa en el gobierno, pertenecían en su mayoría a la Escuela de Cristo: Baltasar Moscoso y Sandoval, arzobispo de Toledo; Pascual de Aragón, inquisidor general, y Guillem Ramón de Montcada, IV marqués de Aytona. Asimismo, el vicecanciller del Consejo de Aragón, don Cristóbal Crespí de Valldaura que, si bien, él no estuvo en la institución, sí pertenecieron dos de sus hermanos, Luis Crespí de Borja y Juan Crespí y Brizuela. 
Con todo, no debió ser fácil la implantación de la Escuela en Madrid. Comenzaron a circular por Madrid versiones distorsionadas de los ejercicios que se practicaban en ella, lo que fue motivo de mofa pública, según se recoge de esta noticia, recogida por Jerónimo de Barrionuevo: «Porque el conde del Puerto aceptó el desafío, le han borrado de la congregación de la Escuela de Cristo, sita en la iglesia de los italianos en Madrid, donde les hacen hacer públicamente algunas penitencias, haciéndose ya agonizantes, ya muertos, ya ciegos, ya cojos, y otras cosas de este tono, y suceden cosas ridículas» (Barrionuevo, 1996, 157). Estas noticias llegaron también a oídos del arzobispo de Toledo, Moscoso, como refiere su biógrafo (Andrade, 1668). Por este motivo salió al paso el obispo Juan Palafox en el memorial dirigido a Moscoso, fechado el 1 de septiembre 1653.

¿Qué medios ofrecía la Santa Escuela para lograr el fin de alcanzar la perfección cristiana? Las mismas que la Iglesia venía ofreciendo: oración, frecuencia de los sacramentos, mortificación, práctica de virtudes y alejarse de las ocasiones de pecado. En este sentido, la Santa Escuela no aportaba ninguna novedad destacable. Ahora bien, como «Madre Maestra» ¿ofrecía una espiritualidad determinada? Valente señala que la Escuela mezcló «corrientes de espiritualidad italiana del siglo XVII y elementos característicos de la espiritualidad española» (Valente, 1991). ¿Existe una espiritualidad propia de la Escuela? Resulta difícil de decir porque no hemos hallado libros donde se especifique su doctrina, pero en los estantes de la mayor parte de los oratorios existían dos libros: las meditaciones de fray Luis de Granada y las del jesuita Luis de la Puente. Tampoco es posible ignorar que el fondo sobre el que se asentó fue la espiritualidad de san Felipe de Neri, transmitida desde los oratorios por Ferruzzo, su fundador. No cabe duda de que Cristo es el centro de la espiritualidad «Aprended de mí, que soy manso y humilde de corazón» (Mt, 11, 29) y todos los demás son sus discípulos (carácter de obediencia). El hermano de la Escuela debía saber conjugar en su vida cotidiana la dimensión activa y contemplativa. A la espera de un estudio más profundo, las notas de espiritualidad de la Escuela podrían resumirse en los siguientes conceptos: cristocéntrica, eclesial, eucarística, mariana y filipense.

Esta espiritualidad se comprende mejor cuando se observan las realizaciones que llevaron a cabo algunos de sus miembros. Don Guillén Ramón de Moncada (1625-1670), marqués de Aytona, se esforzó en implantar una ideología religiosa dentro de su ejército ${ }^{10}$. Aytona escribió un Discurso militar

10 Intervino en la guerra de Cataluña desde 1647. En 1652 fue nombrado consejero de Estado. Felipe IV ordenó en su testamento que fuera uno de los consejeros de la regente Mariana de Austria. 
mientras estuvo preso bajo los franceses (publicado en Valencia en 1653), en el que sentaba las bases del espíritu del soldado: «El tener aplacado a Dios, nuestro señor, y la buena conciencia de los soldados es la primera obligación de que dependen todas las conveniencias y buenos sucesos del ejército y cuanto mira a esto es a lo que se debe atender en primer lugar y a lo que quizá se atiende menos, causa más cierta de los malos sucesos que algunas veces se experimentan, pues sin acudir a Dios no se puede haber buenos sucesos». Parece que siguió las doctrinas del jesuita Adam Contzen, quien afirmaba: «El fin próspero de la guerra y la victoria cada uno lo debe pedir a Dios, que en la guerra las más cosas suceden fuera de la opinión y no se han de considerar sólo las fuerzas en ella, sino la voluntad divina» (libro 10, XIII, 2). Aytona denunciaba la falta de religiosidad en el ejército, por lo que se debía de dar un cambio, ya que «Ésta es la primera virtud del soldado y por la que alcanza la mayor fortaleza». Es decir, en su tratado solo había construcción religiosa, pero ausencia de política militar o defensa de los intereses de la Monarquía.

Cuatro años después de haber iniciado sus ejercicios en Madrid y haberse aprobado sus constituciones, la Escuela de Cristo se estableció en América. La primera Escuela americana fue la de Lima, fundada 1660, por sugerencia de Aytona. En el virreinato del México, las primeras noticias de la fundación de una Escuela son de Guatemala, fundada en 1664, siendo muy probable que, para estas fechas, ya hubiera en México. El iniciador de la Escuela de Lima fue el jesuita Francisco del Castillo, junto con unos piadosos caballeros que dirigía espiritualmente. Castillo había nacido en 1615 y había estudiado en el colegio real de san Martín de la Compañía de Jesús, donde ingresó de novicio. El centro de su actividad lo constituyó la ermita de Nuestra Señora de los Desamparados que, a partir de 1668 y gracias al apoyo del arzobispo y del virrey Lemos, fue reedificada y convertida en colegio de la Compañía de Jesús. Allí se erigió la Escuela de Cristo. A pesar de sus orígenes humildes, mantuvo contacto con la alta sociedad (Buendía, 1693; Vargas Ugarte, 1946; Nieto Vélez, 1992).

\section{REFERENCIAS}

Alba, A. (1992). Los españoles y lo español en la vida de san Felipe Neri. Alcalá de Henares.

Andrade, A. (1668). Idea del perfecto prelado en la vida del ... cardenal don Baltasar Moscoso y Sandoval. Madrid. 
Bacci, P. G. (1673). Vida de San Felipe Neri ... fundador de la Congregación del Oratorio. Valencia.

Baffetti, G. (1997). Retorica e scienza. Cultura gesuítica e Seicento italiano. Bologna.

Barrionuevo, J. (1996). Avisos de Madrid de los Austrias y otras noticias. (Ed., de J. M. Díaz Borque). Madrid.

Brizzi, G. P. (a cura di) (1981). La Ratio studiorum. Modelli culturali e pratiche educative dei Gesuiti in Italia. Roma.

Buendía, J. De (1693). Vida admirable y prodigiosas virtudes del ... padre Francisco del Castillo de la Compañía de Jesús, natural de Lima. Madrid.

Cistellini, A. (1989). San Filippo Neri. L'oratorio e la Congregatione oratoriana. Storia e spiritualità. Brescia.

Crespi de Borja, L. (1653). Propugnaculum theologicum deffinibilitatis sententiae piae negantis B. V. Mariam in primo suae Conceptionis ... Valencia.

Duminuco, V. J. (edit). (2000). The Jesuit Ratio Studiorum. 400 th Anniversary perspectives. New York.

Dupront, A. (1975). D'un humanisme chretien en Italia à la fin du XVIe siécle. Revue historique (175), 296-307.

Frajese, V. (1995). Tendenze dell'ambiente oratoriano durante il pontificato di Clemente VIII. Prime considerationi e linee di ricerca. Roma Moderna e Contemporanea (3), 57-80.

Fattori, M. T. (2004). Clemente VIII e il sacro collegio. Stuttgart.

García Fuertes G. (1992), «Sociabilidad religiosa y círculos de poder. La Escuela de Cristo de Madrid y Barcelona en la segunda mitad del siglo XVII». Pedralbes (13), 319-328.

Garin, E. (1957) L'educazione in Europa (1400-1600). Problemi e programmi. Bari.

Ginnes, F. J. (1995). The Collegio Romano, the Universo of Rome, and the decline and rise of rethoric in the Cinquecento. Roma Moderna e Contemporanea (3), 571-599.

Guicciardini, F. (1890). Historia de Italia donde se escriben todas las cosas sucedidas desde el año 1494 hasta el de 1532. (traducida del italiano por don Felipe IV, rey de España). Madrid.

Hinojosa, R. (1896) Los despachos de la diplomacia pontificia en España. Madrid.

Impagliazzo, M. (1995). I padri dell'Oratorio nella Roma della Contrariforma (15951605). Rivista di Storia e Letteratura religiosa (25) 285-307.

Kowalsky, N. (1965). Sacra Congregactio de Tuenda Fide. Annales Pont. Univ Urbaniana. (12), 26-39.

Labarga García, F. (2013). La Santa Escuela de Cristo. Madrid. BAC.

Labrador, Bertrán-Quera, C. M., Diez Escanciano, A. \& Martínez de la Escalera, J. (1986). La "Ratio Studiorum» de los Jesuitas. Madrid.

León Pinelo, A. (1975). Anales de Madrid. Madrid.

Mattei, R. (1965). Il mito della monarchia universale nel pensiero politico italiano del Seicento. Revista di studi politici internazionali (32), 531-550.

- (1952). Polemiche secentesche italiane sulla Monarchia Universale. Archivio Storico Italiano (110) 145-165.

Martínez Gomis, M. (2002). Las Escuelas de Cristo. Anales de la Universidad de Alicante (20).

Nieto Vélez, A. (1992). Francisco del Castillo, el apóstol de Lima. Lima. 
Pizarro Llorente, H. (2017), «Entre Madrid y Roma: el agente de la Inquisición española Juan Bautista Vives». Dimensioni e problemi de la ricerca storica, (2) 273-300.

Puente, J. De la (1612). Tomo primero de la conueniencia de las dos Monarquías Católicas, la de la Iglesia Romana y la del Imperio Español y defensa de la precedencia de los Reyes Católicos de España a todos los Reyes del mundo. Madrid.

Rivero Rodríguez, M. (2005). Gattinara, Carlos Vy el sueño del Imperio. Madrid: Sílex.

Rodríguez Villa, A, (2011). Memorias del saco de Roma. Madrid.

Salazar, J. De. Política Española (1619). Edición, estudio preliminar y notas de Miguel Herrero García. Centro de Estudios Políticos y constitucionales. Madrid, 1997. (Colección Clásicos del Pensamiento Político y Constitucional Español), 70.

Santos, A. (1972). Orígenes históricos de la Sagrada Congregación «De Propaganda Fide». Revista española de derecho canónico (28), 509-521.

Valente, J. A. (1991), Variaciones sobre el pájaro y la red. Barcelona.

Valero Moreno, M. (1986) La Escuela de Cristo. Su vida, organización y espiritualidad barroca, en: C. Álvarez Santaló, M. J. Buxó i Rey, S. Rodríguez Becerra (Coords), La religiosidad popular. Barcelona, III, pp. 507-529.

Vargas Ugarte, R (1946). Vida del venerable padre Francisco del Castillo. Lima.

Vian Herrero, A. (1994). El diálogo de Lactancio y un arcediano de Alfonso de Valdés, obra de circunstancias y diálogo literario. Toulouse. 